\title{
ZnO光伝導素子を利用したテラヘルツ波発生
}

\author{
小野 晋吾 ${ }^{1}$, 猿倉 信彦 ${ }^{2}$, 福田 承生 ${ }^{3}$ \\ 1名古屋工業大学 (广466-8555 愛知県名古屋市昭和区御器所町) \\ ${ }^{2}$ 大阪大学 レーザーエネルギー学研究センター（テ565-0871 大阪府吹田市山田丘2-6) \\ ${ }^{3}$ 東北大学 原子分子材料科学高等研究機構 ( $\bar{T} 980-8577$ 宮城県仙台市青葉区片平二丁目1番1号)
}

\section{Generation of Terahertz Radiation Using Zinc Oxide as Photoconductive Material}

\author{
Shingo ONO, ${ }^{1}$ Nobuhiko SARUKURA, ${ }^{2}$ and Tsuguo FUKUDA ${ }^{3}$ \\ ${ }^{1}$ Nagoya Institute of Technology, Gokiso-cho, Showa-ku, Nagoya 466-8555 \\ ${ }^{2}$ Institute of Laser Engineering, Osaka University, 2-6 Yamadaoka, Suita, Osaka 565-0871 \\ ${ }^{3}$ Advanced Institute for Materials Research, Tohoku University, 2-1-1 Katahira, Aoba-ku, Sendai, Miyagi 980-8577
}

(Received October 25, 2010)

\begin{abstract}
Terahertz $(\mathrm{THz})$ radiation is generated from photoconductive antennas fabricated on a single crystal zinc oxide $(\mathrm{ZnO})$. The all-solid state UV femtosecond laser is used for excitation. The THz-radiation power shows quadratical dependence on the electric field below $800 \mathrm{~V} / \mathrm{cm}$, and the obtained spectrum extends up to $1 \mathrm{THz}$. Moreover, the high crystallinity of the hydrothermally grown $\mathrm{ZnO}$ single crystal shows high transparency in the visible, near-infrared, and $\mathrm{THz}$ frequency regions. These observed characteristics open up the possibility of using $\mathrm{ZnO}$ in integrated active optics.
\end{abstract}

Key Words: Terahertz radiation, Photoconductive switch, Ultraviolet laser, $\mathrm{ZnO}$

1. はじめに

応用範囲の拡大を続けるテラヘルツ技術において， レーザーを用いた多様なテラヘルツ波光源が利用されて いるが，その中でも光伝導素子を用いた発生法は最も代 表的な手法であり, 現在も広く利用されている.この光 伝導素子は, 超短パルスレーザーを照射することで生成 した光励起キャリアを外部電場で駆動し, 過渡電流とす ることでテラヘルツ波を発生させることができる. 1983 年に, Austonらはサファイア基板上に成長させたシリコ ンのエピタキシャル薄膜 (SOS; Silicon on Sapphire) に $10 \mu \mathrm{m}$ の間隔の電極を作製し，この素子からのテラヘル ツ波発生に成功している ${ }^{1)}$. その後, 半絶縁性ガリウム 砒素 (SI-GaAs; Semi-insulator GaAs) をはじめとする様々 な材料が光伝導体として用いられてきた2,3). 光伝導素 子から発生するテラヘルツ波の出力を効率よく大きくす るための方法の一つは, 電極間に印加する光励起キャリ ア駆動のための電場を強くすることである。そのため, 高電場を印加可能な絶縁破壊しきい值の高いワイド ギャップ材料が注目を集めている。

本研究では, 水熱合成法によって成長した $\mathrm{ZnO}$ 単結晶 基板を用いた光伝導素子からのテラヘルツ波放射を行っ た。 また，テラヘルッ領域における $\mathrm{ZnO}$ の透過特性評価 を行うことで, テラヘルツ光学材料としての可能性につ いても同時に調べたのでこれらについて述べる。
2. 光伝導素子からの高出カテラヘルッ波発生

光伝導素子から発生するテラヘルツ波の出力は, いく つかの理由により飽和し，ある一定以上にはならない. 例えば，境界条件から，電極近傍におけるテラヘルツ波 は以下のように記述できる ${ }^{4,5)}$.

$$
E_{T H z}=-E_{b} \frac{\sigma_{s} \eta_{0}}{\sigma_{s} \eta_{0}+\left(1+\sqrt{\varepsilon_{r}}\right)}
$$

ここで， $E_{b}$ は電極に印加した電場， $\sigma_{S}$ は基板表面におけ る光伝導率, $\eta_{0}$ は真空のインピーダンス, $\varepsilon_{r}$ は基板の比 誘電率である，たとえば，（1）式において $\sigma_{S} \rightarrow \infty$ とする と， $E_{T H z}$ が飽和することが分かる。つまりどんなにレー ザーの励起強度を上げても，発生するテラヘルツ波は $E_{b}$ 以上にはならない。そのため, 高出力のテラヘルツ波を 得るためには，電極間により大きな電場をかけることが 必要であり，また。居をきくするために，移動度が大き い半導体材料を, より強い光で励起する必要がある. GaAsが光伝導素子に広く用いられる理由の一つは, 約 $3000 \mathrm{~cm}^{2} / \mathrm{Vs}$ という高い移動度にある。

またより高出力のテラヘルッ電磁波を得るために，大 口径 (large-aearture) 光伝導素子が提案されている。これ は，電極間隔を数 $\mathrm{mm}$ 数 $\mathrm{cm}$ 程度と大きく広げ，それに 合わせた大きなスポットサイズのパルス光で励起するも ので，テラヘルツ波の放出面積を拡大することで発生す 
るテラヘルツ波を高出力化するというものである，電極 間隔が広くて励起光があまり集光できない場合, チャー プパルス増幅などによる励起光の高出力化が必要であ る.さらにこの手法は, 電極間のテラヘルツ波放出領域 が波長に比べて十分に大きいため, テラヘルツ波は励起 光と同軸上に放出されるという特徵を持っている. You らは, 半導体基板にGaAsを用い, 電極間隔 $1 \mathrm{~cm}$ の光伝 導素子から, 高出力のテラヘルッ波を発生させてい $る^{6)}$.

\section{3. ワイドギャップ材料を用いた光伝導素子}

光伝導素子の電極間に印加できる電場の条件は, 基板 に使用した光伝導材料の絶縁破壊しきい值によって決ま る. 現在基板材料として一般的に用いられているのは, 半絶縁性ガリウム砒素であるが, その絶縁破壊しきい值 は約 $10^{4} \mathrm{~V} / \mathrm{cm}$ である。一方様々な半導体材料の中で, 最 大のしきい值を持つものはダイヤモンドであり, その值 は $10^{6} \mathrm{~V} / \mathrm{cm}$ 以上である。このようなダイヤモンドなどの ワイドギャップ材料を用いた光伝導素子は, 火炎検出等 における紫外線モニタリング用フィルタレスセンサなど に利用される一方で, テラヘルツ電磁波発生用素子とし ても注目されている7). Yonedaらは, CVD法(化学気相 成長法)によって作製された大面積多結晶ダイヤモンド 膜を光伝導材料とし，その上にアレー状に作製した電極 に $10^{5} \mathrm{~V} / \mathrm{cm}$ の電場を印加することで, 光伝導素子からの 高出力テラヘルツ波発生について報告している ${ }^{8)}$. しか し，ダイヤモンドは，そのバンドギャップの大きさ $(5.5 \mathrm{eV})$ から, 励起光源に $\mathrm{KrF}$ エキシマレーザーを必要 とする9 . エキシマレーザーは小型化が難しく, 固体 レーザーに比べ, 安定性, ランニングコストといった問 題点がある.さらにダイヤモンドに関しても, 大型の単 結晶を手に入れることが難しく, 多結晶薄膜のキャリア の移動度 $\left(70 \mathrm{~cm}^{2} / \mathrm{Vs}\right)$ は, 単結晶の移動度 $\left(1800 \mathrm{~cm}^{2} / \mathrm{Vs}\right)$ に比べてかなり小さくなる.

これに対して, 本研究で用いた $\mathrm{ZnO}$ は光デバイス応用 などを見据えた結晶成長技術が急速に発達しており，水 熱合成法により大型で高品質な単結晶作製が可能であ る。これを用いることで, 単結晶上への大口径光伝導ス イッチの作製が可能であり, $200 \mathrm{~cm}^{2} / \mathrm{Vs}$ という移動度 は, 多結晶ダイヤモンド薄膜に比べると数倍の大きさで ある ${ }^{10)}$ 。また, $\mathrm{ZnO}$ 単結晶の透過端は390 nm(バンド ギャップ $3.2 \mathrm{eV})$ であり, チタンサファイアレーザーの 第2もしくは第3高調波で励起することができる。この波 長変換のためには, $\mathrm{CsLiB}_{6} \mathrm{O}_{10}, \mathrm{LiB}_{4} \mathrm{O}_{7}, \mathrm{BaB}_{2} \mathrm{O}_{4}, \quad \mathrm{LiB}_{4} \mathrm{O}_{7}$ などの非線形光学結晶が揃っており，それに加えて， $\mathrm{Ce}^{3+}: \mathrm{LiCaAlF}_{6}(\mathrm{Ce} ; \mathrm{LiCAF}), \mathrm{Ce}^{3+}: \mathrm{LiSrAlF}_{6}, \mathrm{Ce}^{3+}: \mathrm{LiLuF}_{4}$ な どの紫外レーザー材料を用いたチャープパルス増幅が可 能である ${ }^{11-18)}$ 。これらのレーザー材料の中でも特に Ce:LiCAFは劣化についての報告がなく, Nd:YAGレー ザーの第4高調波で励起可能であり, 超短パルスの発生 や増幅に適した波長2 80 から320 nmに及ぶ非常に広い利 得帯域幅を持っている。この単結晶を用いたチャープパ

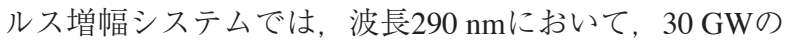

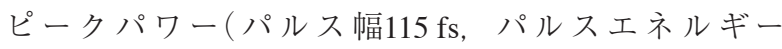
$3.5 \mathrm{~mJ})$ が得られている ${ }^{15)}$. 近年では大型の高品質結晶 の育成も可能になっており，大口径Ce:LiCAF結晶を用 いたパワー増幅器からは98 mJのパルスエネルギーが得 られている ${ }^{16)}$ 。このように，ワイドギャップ材料の励起 に必要な固体レーザー光源に関する技術は確立されてき ている.

今回テラヘルッ波発生に用いた光伝導素子には, $10 \mathrm{~mm}$ 角, 厚さ $0.5 \mathrm{~mm}$ $\mathrm{ZnO}$ 単結晶基板上に電極間隔 $1 \mathrm{~mm}$ のストリップライン型銀電極 (長さ $5 \mathrm{~mm}$, 幅 $1 \mathrm{~mm}$ ) を作製し，大口径光伝導素子とした ${ }^{19-20)}$ 。この電極間 に, チタンサファイア再生増幅器からのレーザーパルス の第3高調波(波長：290 nm, 繰り返し周波数: $1 \mathrm{kHz}$, 平均出力 : $25 \mathrm{~mW}$, パルス幅 : $200 \mathrm{fs}$ )をシリンドリカル レンズで集光し, $1 \mathrm{~mm} \times 5 \mathrm{~mm}$ のスポットサイズで照射 した。テラヘルツ波の出力は, 液体へリウム冷却型ゲル マニウムボロメーターでロックイン検波し，スペクトル は, 偏光フーリエ干渉分光器で分光した. Fig. 1に, 発 生したテラヘルツ波の出力と光伝導素子への印加電場の 関係を示す，光伝導素子の電極間に $2 \mathrm{kV} / \mathrm{cm}$ までの電場 を印加し，テラヘルツ波の出力を測定した結果， $800 \mathrm{~V} / \mathrm{cm}$ 越えたあたりでテラヘルツ波出力の飽和が観 測された。これは励起レーザーの出力が十分でないた め, 光励起キャリアが少なく, 暗電流の影響が強く出た と考えられる。 $\mathrm{ZnO}$ 結晶の絶縁性を高め, 暗電流の影響 を軽減できれば, より高出力のテラヘルツ波発生も期待 できる，本実験では， $2 \mathrm{kV} / \mathrm{cm}$ 以上の電場では，電流值 の増加により定電圧電源の安全装置が働くため, これよ り高い電場を印加していないが，文献20のZnO薄膜を用 いた光伝導素子には $14 \mathrm{kV} / \mathrm{cm}$ までの電界を加えている. これ以上では電極が先に破壊したが, GaAsよりも大き い絶縁破壊しきい值が期待できる。Fig. 2 に実測された テラヘルツ波スペクトルを示す。およそ $0.35 \mathrm{THz}$ 付近を

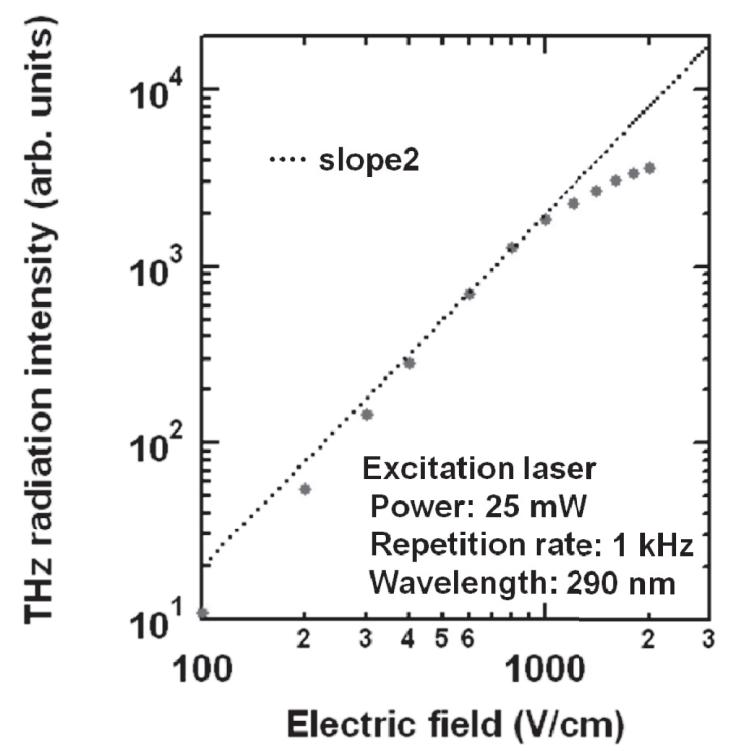

Fig. $1 \mathrm{THz}$ radiation power dependence on the electric field. Saturation is observed above $800 \mathrm{~V} / \mathrm{cm}$. 


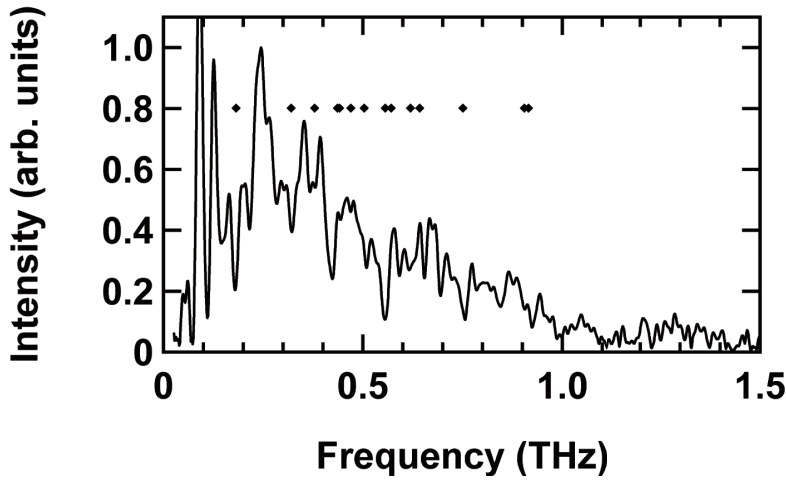

Fig. $2 \mathrm{THz}$ radiation spectrum from a $\mathrm{ZnO}$ photoconductive switch.

中心に，1 THzにおよぶ幅広いスペクトルが観測され た. スペクトル全域にわたって現れているくで示した鋭 い吸収線は, 大気中の水蒸気吸収である ${ }^{21)}$.

\section{4. テラヘルツ領域における光学材料としてのZnO}

現在, 光伝導素子から発生させたテラヘルツ波を利用 した分光計測を行う場合, 放物面鏡を用いて集光し, サ ンプルに照射することがほとんどである。これは, 紫外 〜近赤外領域で用いられるような一般的な光学素子は, テラヘルツ領域の光を透過しないため使用できず，また この領域で使用するような光学系の開発が進んでいない ことが原因である。しかしこのように自由空間にシステ ムを組み上げると, 調整が大変な上, 大気中の水蒸気に よるテラヘルッ電磁波の吸収があり，これを避けるため には装置が大きくなってしまう。そのため，これらの問 題を克服するための光導波路に利用可能な光学材料が求 められている22).

Fig. 3 (a) はテラヘルツ領域におけるZnO単結晶の透過 スペクトルを示しており，この測定には，磁場中配置し たインジウム砒素に超短パルスレーザーを照射し発生さ せたテラヘルツ波を用いた ${ }^{22-24)}$. 図の周期構造は結晶の 表面と裏面からの反射波の干渉によるものである。この 周期構造の間隔から $\mathrm{ZnO}$ の屈折率を見積もることがで き, $\mathrm{ZnO}$ の屈折率を2.9とし, 以下の式でフィッティン

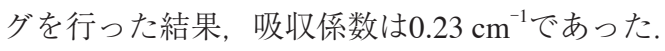

$$
T=\frac{\left(1-R_{0}\right)^{2} e^{-\alpha d}}{\left(1-R_{0} e^{-\alpha d}\right)^{2}+4 R_{0} e^{-\alpha d} \sin ^{2} \frac{2 \pi}{\lambda} n d}
$$

ここで, $R_{0}=\frac{(n-1)^{2}+\kappa^{2}}{(n+1)^{2}+\kappa^{2}}$ は反射率, $\alpha=\left(\frac{4 \pi \kappa}{\lambda}\right)$ は吸収 係数, $\kappa$ は減衰係数, $\lambda$ は波長, $d$ はサンプルの厚みであ る.

このように，テラヘルツ領域での優れた透過特性を持 つZnOは, これまでテラヘルツ波発生に用いられてきた $\mathrm{Si}$ PaAsとは異なり, Fig. 3 (b) に示すように可視から 近赤外領域においても高い透過率を示す。 そのため, 幅 広い波長領域に対応する扱いやすい光学素子設計を可能 にする，たとえば，以前我々はポリメチルペンテン

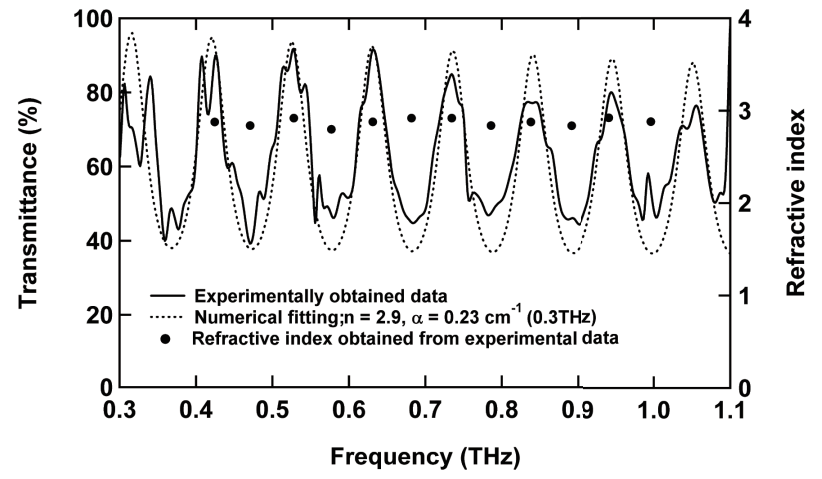

(a)

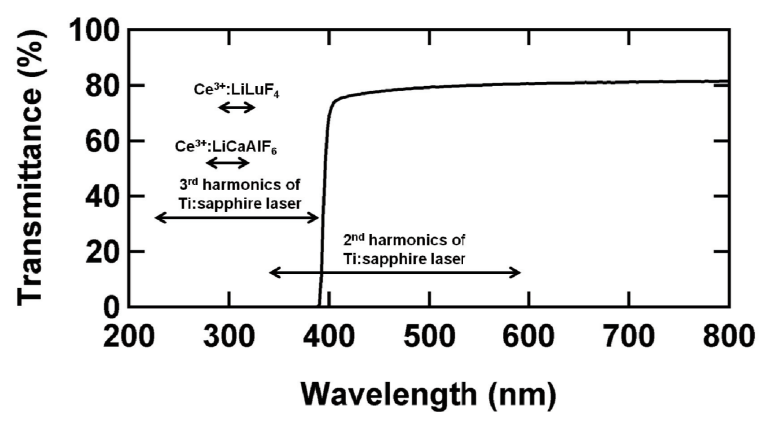

(b)

Fig. 3 (a) Transmission spectrum of a $\mathrm{ZnO}$ single crystal in the THz region. The periodic structure is due to the interference from the front and back surfaces of the $\mathrm{ZnO}$ crystal. (b) Transmission spectrum in the visible, near-infrared and mid-infrared regions.

(TPX) を用いたテラヘルツ波用レンズダクトと呼ばれる 集光用光学素子を開発しているが, TPX(屈折率1.4)に

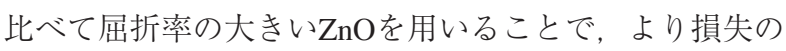
少ないレンズダクトの設計が可能である上に，光源と集 光素子を一体化させたより扱いやすいデバイス作製も期 待できる ${ }^{25)}$.

\section{5. まとめと今後の展望}

本稿では, $\mathrm{ZnO}$ のテラヘルツ波発生用光伝導材料と屈 折光学素子材料としての特性について述べた。最近のテ ラヘルツ波発生に関する研究は, 単に高出力のテラヘル ツ波を発生させるというだけでなく, 発生したテラへル ツ波をいかに効率よく利用できるかという点が重要に なっている。この点で, $\mathrm{ZnO}$ のテラルツ波領域におけ る光学特性はきわめて優れたものである，さらに，結晶 成長技術の進歩によって, 大型で高品質な単結晶が手に 入りやすくなっていることもあり, 今後 $\mathrm{ZnO}$ 用いたテ ラヘルツ研究の進展が期待できる.

\section{参考文献}

1) D. Auston and P. Smith: Appl. Phys. Lett. 43 (1983) 631.

2) S. Gupta, J. Whitaker, and G. Mourou: IEEE J. Quantum Electron. 28 (1992) 2464.

3) M. Tani, M. Matsuura, and K. Sakai: Appl. Opt. 36 (1997) 7853.

4) B. B. Hu, J. T. Darrow, X.-C. Zhang, D. H. Auston, and P. R. Smith: Appl. Phys. Lett. 56 (1990) 886. 
5）村上 英俊, 小野晋吾, 猿倉 信彦：応用物理 75 (2006) 202.

6) D. You, R. R. Jones, P. H. Bucksbaum, and D. R. Dykaar: Opt. Lett. 18 (1993) 290.

7) K. Hayashi, T. Tachibana, N. Kawakami, Y. Yokota, K. Kobashi, H. Ishihara, K. Uchida, K. Nippashi, and M. Matsuoka: Jpn. J. Appl. Phys. 44 (2005) 7301.

8) H. Yoneda, K. Tokuyama, K. Ueda, H. Yamamoto, and K. Baba: Appl. Opt. 40 (2001) 6733.

9) Y. Nabekawa, K. Kondo, N. Sarukura, K. Sajiki, and S. Watanabe: Opt. Lett. 18 (1993) 1922.

10) K. Maeda, M. Sato, I. Niikura, and T. Fukuda: Semicond. Sci. Technol. 20 (2005) S49.

11) Y. Mori, I. Kuroda, S. Nakajima, T. Sasaki, and S. Nakai: Jpn. J. Appl. Phys. 34 (1995) L296.

12) R. Komatsu, T. Sugawara, K. Sassa, N. Sarukura, Z. Liu, S. Izumida, Y. Segawa, S. Uda, T. Fukuda, and K. Yamanouchi: Appl. Phys. Lett. 70 (1997) 3492.

13) Y. Suzuki, S. Ono, H. Murakami, T. Kozeki, H. Ohtake, N. Sarukura, G. Masada, H. Shiraishi, and I. Sekine: Jpn. J. Appl. Phys. 41 (2002) L823.

14) M. Dubinskii, V. Semashko, A. Naumov, R. Abdulsabirov, and S. Korableva: J. Mod. Opt. 40 (1993) 1.

15) Z. Liu, T. Kozeki, Y. Suzuki, N. Sarukura, K. Shimamura, T. Fukuda, M. Hirano, and H. Hosono: Opt. Lett. 26 (2001) 301.

16) S. Ono, Y. Suzuki, T. Kozeki, H. Murakami, H. Ohtake, N. Sarukura, H. Sato, S. Machida, K. Shimamura, and T. Fukuda:
Appl. Opt. 41 (2002) 7556

17) N. Sarukura, Z. Liu, Y. Segawa, K. Edamatsu, Y. Suzuki, T. Itoh, V. V. Semashko, A. K. Naumov, S. L. Korableva, R. Y. Abdulsabirov, and M. A. Dubinskii: Opt. Lett. 20 (1995) 294.

18) J. L. Gabayno, M. Cadatal-Raduban, M. Pham, K. Yamanoi, E. Estacio, W. Garcia1, T. Nakazato, T. Shimizu, N. Sarukura, T. Suyama, K. Fukuda, K. J. Kim, A. Yoshikawa, and Fumio Saito: Jpn. J. Appl. Phys. 48 (2009) 120213.

19) S. Ono, H. Murakami, A. Quema, G. Diwa, N. Sarukura, R. Nagasaka, Y. Ichikawa, E. Ohshima, H. Ogino, A. Yoshikawa, and T. Fukuda: Appl. Phys. Lett. 87 (2005) 261112.

20) R. Umezawa, R. Nagasaka, M. Cadatal, S. Ono, N. Sarukura, and Y. Ichikawa: Jpn. J. Appl. Phys. 48 (2009) 030209.

21) H. M. Pickett, R. L. Poynter, and E. A. Cohen: Submillimeter, Millimeter, and Microwave Spectral Line Catalog, accessed via World Wide Web (http://spec. jpl.nasa.gov) from the Jet Propulsion Laboratory, Pasadena, California.

22) X. C. Zhang, Y. Lin, T. Hewitt, T. Sangsiri, L. Kingsley, and M. Weiner: Appl. Phys. Lett. 62 (1993) 2003.

23) N. Sarukura, H. Ohtake, S. Izumida, and Z. Liu: J. Appl. Phys. 84 (1998) 654.

24) H. Ohtake, S. Ono, M. Sakai, Z. liu, T. Tsukamoto, and N. Sarukura: Appl. Phys. Lett. 76 (2000) 1398.

25) M. Goto, A. Quema, H. Takahashi, S. Ono, and N. Sarukura: Jpn. J. Appl. Phys. 43 (2004) L317. 